\title{
Climate factors and limnological conditions shaping phytoplankton community in two subtropical cascading reservoirs
}

Fatores climáticos e limnológicos influenciam a estrutura da comunidade fitoplanctônica em dois reservatórios subtropicais de um sistema em cascata

Ana Paula Vestena Cassol ${ }^{1 *}$, Maria Angélica Oliveira ${ }^{1}$, André Luis Domingues ${ }^{1}$, Waterloo Pereira-Filho ${ }^{1}$, Mariana Durigon ${ }^{1}$ and Juliana Ferreira da Silva ${ }^{1}$

${ }^{1}$ Universidade Federal de Santa Maria - UFSM, Av. Roraima, 1000, Cidade Universitária, Camobi, CEP 97105-900, Santa Maria, RS, Brazil

*e-mail: anapvcassol@gmail.com

Cite as: Cassol, A.P.V. et al. Climate factors and limnological conditions shaping phytoplankton community in two subtropical cascading reservoirs. Acta Limnologica Brasiliensia, 2017, vol. 29, e17.

Abstract: Aim: A series of dams along the course of a river forms a complex cascading reservoir system. The interconnectivity of the dams is perceived with the reduction of turbidity and phosphorus and the increase of specific richness throughout the system. Designing a management system that promotes the integration of biotic and abiotic data is essential to these resources of recognized importance for the population, the country's power generation and watersheds management. The Jacuí River is an important water resource in the state of Rio Grande do Sul, along its upper course, five water reservoirs comprise a cascade system tapped for energy generation and agriculture, but the effects on the phytoplankton community of cascading dams are still unknown. Thus, the present study aimed to investigate spatial and temporal patterns of phytoplankton associated with climatological and limnological characteristics of the Ernestina and Itaúba water reservoirs, located in the upper Jacuí River, RS, Brazil. Methods: Sampling campaigns were carried out seasonally from January 2012 to February 2013, with four sampling stations within each dam and at three different depths. The sampling units were determined according to the three zones of the reservoir: river areas, transition and lake. Results: A total of 91 phytoplankton species were identified in Ernestina and 130 in Itaúba. There was no significant difference between vertical and horizontal patterns, since the community responded to seasonal changes and the specific characteristics of each dam. Conclusions: The specific richness and water transparency increased downstream of the system and changes in water retention time were important for cell density and composition.

Keywords: Plankton; seasonality; ecological dynamics; retention time.

Resumo: Objetivo: Uma série de represas ao longo do curso de um rio formam o complexo sistema em cascata de reservatórios. A interconectividade dessas represas são percebidas com a redução da turbidez e fósforo e aumento da riqueza de espécie ao longo do sistema. Além disso, cada reservatório possui suas características, bióticas e abióticas, que devem ser avaliadas e utilizadas como instrumento na elaboração de propostas de manejo contínuo das bacias hidrográficas. O rio Jacuí, com cinco represas inseridas ao longo do seu curso superior, é um importante recurso hídrico do estado do RS, explorado para geração de energia e agricultura, no entanto seus efeitos na comunidade fitoplanctônica das represas construídas em cascata ainda é desconhecido. Dessa forma o presente estudo teve como objetivo investigar padrôes espaciais e temporais do fitoplâncton associadas às características climatológicas e 
limnológicas dos reservatórios de água Ernestina e Itaúba, localizados no curso superior do rio Jacuí, RS, Brasil. Métodos: Campanhas amostrais foram realizadas sazonalmente de janeiro de 2012 a fevereiro de 2013, com quatro estaçóes amostrais dentro de cada represa e em três diferentes profundidades. As unidades amostrais foram determinadas de acordo com as três zonas do reservatório: zonas de rio, transição e lago. Resultados: Foram identificadas 91 espécies fitoplanctônicas em Ernestina e 130 em Itaúba. Não houve diferença significativa entre padrōes verticais e horizontais, pois a comunidade respondeu a mudanças sazonais e as características especificas de cada represa. Conclusóes: A riqueza de espécies e a transparência da água aumentou a jusante do sistema e alteraçóes no tempo de retenção da água foram importantes para densidade e composição de células.

Palavras-chave: Plâncton; sazonalidade; dinâmica ecológica; tempo de retençấo.

\section{Introduction}

A cascading reservoir system is formed when a series of dams is constructed along the course of a river. The interconnectivity among the reservoirs may be observed along the system through patterns described in the Cascading Reservoir Continuum Concept by Barbosa et al. (1999). The concept postulates that a progressive reduction of trophic state should be expected along reservoir cascades, also observed by Padisák et al. (2000) in the Tietê basin. However, Nogueira et al. (2010) observed in Paranapanema basin increased trophic conditions (and phytoplankton abundance) in the mid cascade zone. However, each reservoir also exhibits a horizontal and vertical gradient and their trophic state results of complex interactions of natural and artificial causes (Esteves, 1998). Typically, reservoirs are horizontally structured in three zones: the first one, where the water flows in, is characterized as a river zone (lotic), with elevated turbidity. The second is a transition zone, with increased light availability, and consequent increase in phytoplankton. Finally a lake zone (lentic) is located near the dam, where primary production is often decreased due to nutrient limitation (Kimmel et al., 1990).

In South America, construction of river dams for hydropower generation has been intensified since 1950 (Tundisi \& Matsumura-Tundisi, 2003), with several cascade systems operating in large rivers. The increasing number of reservoirs shows their important role for human populations, such as power generation, supply and recreation (Tundisi \& Matsumura-Tundisi, 2003). Their imposition on natural systems, however, causes significant modifications of hydrology, morphology and riverine habitats, changes which have been well documented (Smith et al., 2014).

Reservoir water quality is a result of several interacting factors, including morphometrics, surrounding vegetation, land use, water retention time and environmental conditions (Tundisi $\&$ Matsumura-Tundisi, 2003). Also, mixing processes and thermal stratification are important phytoplankton community regulators (Gomes \& Miranda, 2001). Morais et al. (2010), for example, showed mixing processes of subtropical reservoirs few days prior to a cold front passage. Reservoirs with longer water retention times provide ideal conditions for phytoplankton blooms, by retaining algal biomass for longer periods (Soares et al., 2008). However, mixing process may trigger algal blooms when nutrients are ressuspended and newly available in water layer, as shown by Nogueira et al. (2010).

While light and temperature are forces that drive annual patterns in phytoplankton assemblages, in temperate waters (Reynolds, 2006), in subtropical areas the primary productivity seems to be influenced by the natural variability between seasons (Schneck et al., 2011) and hydrological conditions (Nogueira et al., 2010). Thus, knowledge of spatial heterogeneity and temporal patterns of these reservoirs, can provide subsidies for the elaboration of proposals for handling and management of the basins which allows to establish a continuous monitoring in these systems.

In Brazil, despite the large number of cascading reservoirs, microalgal ecology studies in such systems are still few and recent (Barbosa et al., 1999); In southern Brazil, where there are well defined seasons, to date, there are no published studies of complete cascading systems. The area that constitutes the Jacuí River is one of the main hydrographic basins in the state of Rio Grande do Sul, with importance in the production of energy, supply of adjacent populations and source of resources for agriculture (CEEE-GT, 2010a, b). This system has not been studied in the context of cascade systems. In the upper Jacuí course, only Dona Francisca reservoir, to our knowledge, has been studied to date (Torgan et al., 1981; Werner \& Laughinghouse IV, 2009; Schneck et al., 2011; Rodrigues et al., 2012) and Itaùba reservoir (Cassol et al., 2014). 
Thus, this study aimed to identify which conditions shape phytoplankton community structure, through analyses of spatial and temporal patterns, associated to limnological variables and environmental conditions in two reservoirs of a cascading system in the upper course of the River Jacuí, southern Brazil. We hypothesized that the phytoplankton community will show horizontal structuring according to three zones: river, transition and lake (Kimmel et al., 1990) and that vertical distribution will be mostly regulated by light availability. Furthermore, the reservoirs will present spatial heterogeneity because they present distinct water retention characteristics, occupation of the environment and morphometry, and also by the influence of the cascade damming system.

\section{Material and Methods}

The River Jacuí is located in Rio Grande do Sul state, Southern Brazil, with 710 kilometres in length. Along its upper course, five water reservoirs comprise a cascade system (Upper River Jacuí Reservoirs) used for hydroelectric power generation (CEEE-GT, 2010a, b). The drainage area essentially consists of agricultural land and pastures, with the presence of several small towns, but no significant industrial activity. The hydroelectric power stations (HPS) of Ernestina and Itaúba are the first and fourth dams, respectively, along the system. Table 1 gives a summary of the main characteristics of these water bodies. Itaúba Reservoir, built 21 years after the reservoir of Ernestina, has higher total volume of accumulated water and a greater depth, characteristics that compose the run-of-river type and present a greater potential of energy generation. Conversely, Ernestina is a dam with a greater perimeter and water retention time.

For this survey, water samples were collected in four occasions (between January 2012 and February 2013) in the two reservoirs, with three sampling sites in Ernestina and four in Itaúba. The sampling sites were determined according to three zones - river, transition zone and lake - as described by Kimmel et al. (1990), (Figure 1). Also, three depths were sampled at each site: surface; depth of disappearance of the Secchi disk, and lower limit of the photic zone, established as three times the depth of disappearance of the Secchi disk, where

Table 1. Description of Ernestina and Itaúba reservoirs and respective hydroelectric power stations, located in the upper course of the River Jacuí, Rio Grande do Sul, Brazil.

\begin{tabular}{lcc}
\hline & Ernestina & Itaúba \\
\hline $\begin{array}{l}\text { Beginning of operation } \\
\text { (year) }\end{array}$ & 1957 & 1978 \\
Area $\left(\mathrm{Km}^{2}\right)$ & 45.4 & 14 \\
Perimeter $(\mathrm{Km})$ & 162.4 & 140.5 \\
Potency $(\mathrm{MW})$ & 4.8 & 500 \\
Total volume $\left(\mathrm{hm}^{3}\right)$ & 274.8 & 620 \\
Average depth $(\mathrm{m})$ & 7.1 & 40 \\
Maximum depth $(\mathrm{m})$ & 17.7 & 90 \\
$\begin{array}{l}\text { Average depth of photic } \\
\text { zone (m) }\end{array}$ & 1.6 & 5.7 \\
$\begin{array}{l}\text { Average retention time } \\
\text { (days) }\end{array}$ & 198 & 19 \\
\hline
\end{tabular}

Source: CEEE-GT (2010a, b).
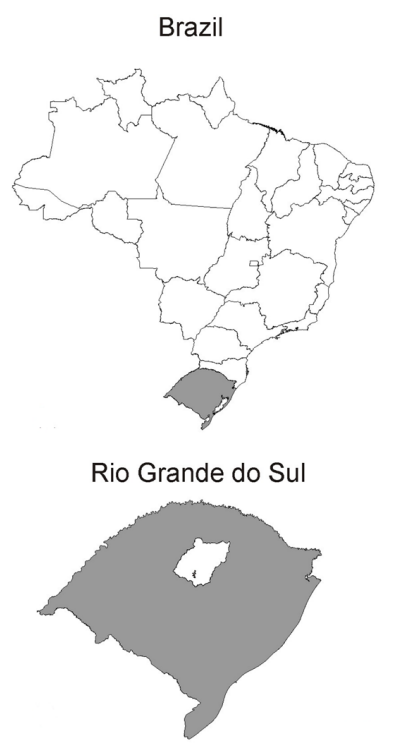

Ernestina Reservoir

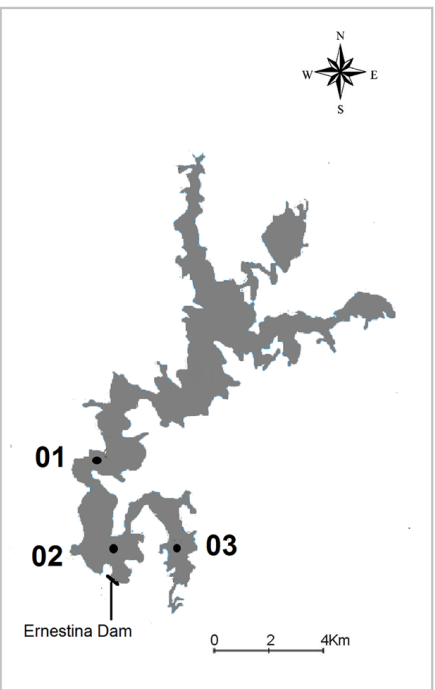

Itaúba Reservoir

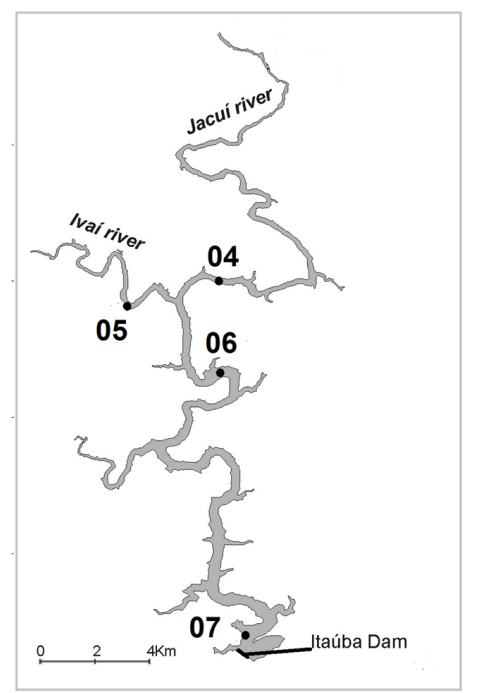

Figure 1. Map showing the position of the reservoirs in Brazil (top left), in Rio Grande do Sul state (bottom left), and the distribution of sampling stations in the reservoirs Ernestina (centre) and Itaúba (right). 
intensity of radiation equals $1 \%$ of that reaching the surface (Esteves, 1998). Phytoplankton samples were taken using a five litre Van Dorn bottle, filtering the contents through a $2.0 \mu \mathrm{m}$ mesh plankton net, preserved on site with $1 \%$ acetic lugol solution. The water samples were filtered in a plankton net to allow transport of the material to the laboratory, because of the large number of flasks that corresponded to the sampling stations and their respective depths in the two reservoirs.

The following limnological variables were measured in each sampling site: water temperature, dissolved oxygen, electric conductivity, $\mathrm{pH}$ and total suspended solids were measured according to APHA (2005); water transparency was calculated with the depth of disappearance and reappearance of the Secchi disk. Total phosphate content of water was determined by inductively coupled plasma-optical emission spectrometry (ICP-OES) (values below the limit of detection have been replaced by the value of the limit of detection). All of the abiotic variables were obtained in the same occaions as the biological ones. Vertical profiles of water temperature and dissolved oxygen were measured in Ernestina and Itaúba reservoirs at two sampling dates using a handheld multi-parameter probe (Horiba- HU40). For reasons of availability the probe was used only in the last two sampling campaigns, and the profiles were measured up to six meters, representing the lower mean limit of the euphotic zone. Rainfall data of each municipality in the drainage area were acquired from the data base of the National Institute of Meteorology (INMET, 2013). Rainfall data for the Ernestina reservoir were obtained from the Passo Fundo meteorological station, 33 kilometres away from the lake. For the Itaúba reservoir, rainfall data were obtained from the meteorological station in Cruz Alta, $90 \mathrm{~km}$ away from the lake. Inflow and outflow data of each reservoir were given by the National Operator of the Electric System (ONS, 2013). Water retention time for each reservoir was calculated according to Spellman (2008).

Phytoplankton genera were identified according to the system of Bicudo \& Menezes (2006). Infra-generic taxa were identified using specialized publications. Quantitative analysis was carried out according to Utermöhl (1958) using an inverted microscope. For the density calculation, the value of the sedimented volume used in the formula was recalculated so that the sample represented the relative proportion to 5 liters, by a cross-multiplication. Counts were performed in random fields. Biovolume of phytoplankton was estimated following the equations given by Hillebrand et al. (1999) and Sun \& Liu (2003).

Structural patterns in the phytoplankton community were analysed using cell density and environmental variables by Non-metric Multidimensional Scaling (NMDS) of the Bray-Curtis similarity matrix. Vectors of the limnological variables were adjusted to the resulting bi-dimensional map using the function EnvFit. Differences among sampling dates, sampling sites, and depths were tested using the analysis of similarity ANOSIM (cell density data). All analyses were performed using the Vegan package (Oksanen et al., 2009) on R 3.0.2 (R Core Team, 2013).

\section{Results}

Throughout the sampling period for Ernestina and Itaúba reservoir, total monthly rainfall values were lower, with a noticeable increase only in June 2012 (CEMET, 2012). The highest average monthly rainfall was in October 2012 and the lowest in August 2012 (Figure 2) for Ernestina. For the Itaúba reservoir, the highest total rainfall value was registered in December 2012 and the lowest in May 2012 (Figure 2).

Ernestina and Itaúba reservoirs present differences in the water retention time. The yearly average water retention time was 198 days in Ernestina reservoir, with the lowest value in August and highest in April 2012. Yearly average water retention time was 19 days, and the highest value was found in May and the lowest in October 2012 (Figure 3).

Figure 4 shows oxygen and temperature vertical profiles. In Itaúba, both thermal and chemical homogeneous conditions were evident in February 2013 (Figure 4g, h).

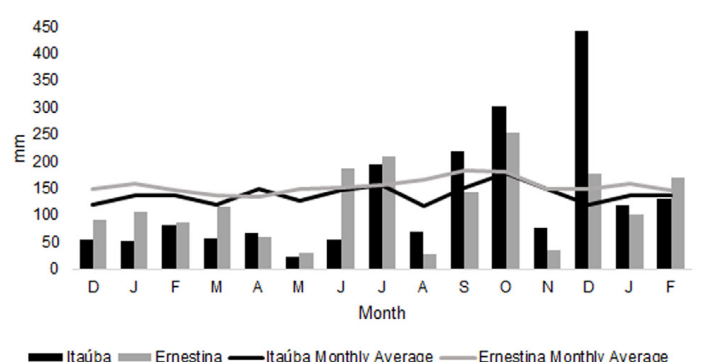

Figure 2. Total monthly rainfall (bars) and average pluviometric levels (lines) between December 2011 and February 2013. Data were obtained from the Passo Fundo Meteorological Station, in the Ernestina reservoir drainage area, and from the Cruz Alta Meteorological Station, located in the Itaúba reservoir drainage area. 
Analysis of the horizontal profile in Ernestina showed less variation than showed by the vertical profile considering temperature. There was a decrease towards the lake zone, near the dam. Water transparency did not show marked horizontal structuring either.

Still in Ernestina, considering seasonal variations, the lowest transparency was found in May and September 2012 (Autumn and Winter), when total suspended solids were also highest (Figure 5). In the Summer, water transparency was deeper near the dam, when total suspended solids were also lower. $\mathrm{pH}$ average values were 6.7 throughout the sampling dates, excluding September 2012, when it reached 7.2 (Figure 5). Values of phosphate were only found above the $25 \mu \mathrm{g}$. $\mathrm{L}^{-1}$ detection limit in January 2012, with maximum of $150 \mu \mathrm{g} . \mathrm{L}^{-1}$.

In Itaúba, the photic zone had its greatest depth near the dam, in the lake zone of the reservoir,

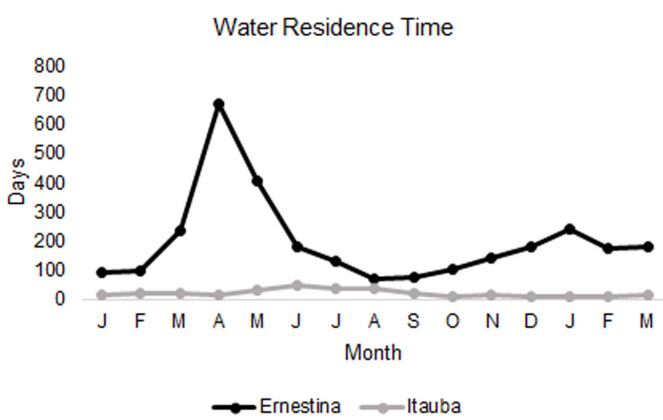

Figure 3. Average water retention time in in the Ernestina and Itaúba reservoirs between January 2012 and March 2013. decreasing gradually towards the River Ivaí confluence, excluding the values obtained in August 2012 when the greatest transparency was found in the river zone. In May 2012 (Autumn) the highest transparency value was found, with the lowest value in August 2012 (Winter). pH in Itaúba generally was slightly acidic, towards neutral. In August, however, 9.2 was found in most sampling stations. Electric conductivity had a narrow range between sampling units. Phosphate values were above the detection limit only in February 2013 (Figure 5).

\subsection{Phytoplankton community structure}

91 species were identified in the phytoplankton community of Ernestina in total, distributed in nine classes: Chlorophyceae 34\%, Cyanophyceae 23\%, Bacillariophyceae 14\%, Zygnemaphyceae 9\%, Euglenophyceae 7\%, Dinophyceae 6\%, Cryptophyceae $4 \%$, Chlamydophyceae $2 \%$ and Crysophyceae 1\%. 11 of these were exclusively found in this reservoir. The highest species richness was found in the last sampling date, January 2013, and the lowest was found in September 2012 (Figure 6). It is interesting to point out that species richness was high in the lower limit of the photic zone, usually greater or the same as the number of species found in the surface (17 species in average).

Qualitative analysis of phytoplankton in Itaúba reservoir revealed 130 species belonging to ten different classes, distributed as follows: Chlorophyceae $41 \%$, Cyanophyceae 16\%, Bacillariophyceae $14 \%$, Zygnemaphyceae 8\%, Dinophyceae 8\%, Chlamydophyceae $4 \%$, Cryptophyceae $3 \%$,
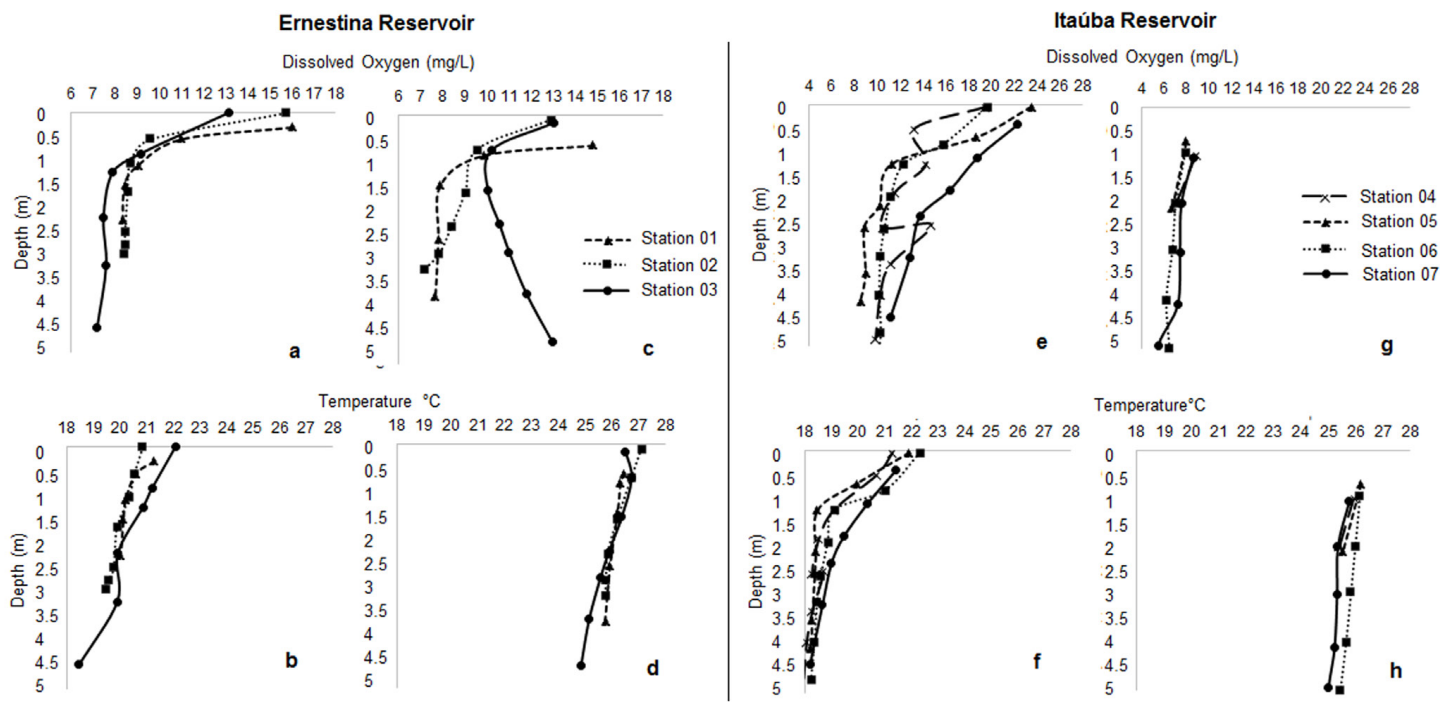

Figure 4. Dissolved oxygen and water temperature vertical profiles in Ernestina in September 2012 (a and b) and January 2013 (c and d) and Itaúba in August 2012 (e and f) and February 2013 (g and h). 
Ernestina Reservoir
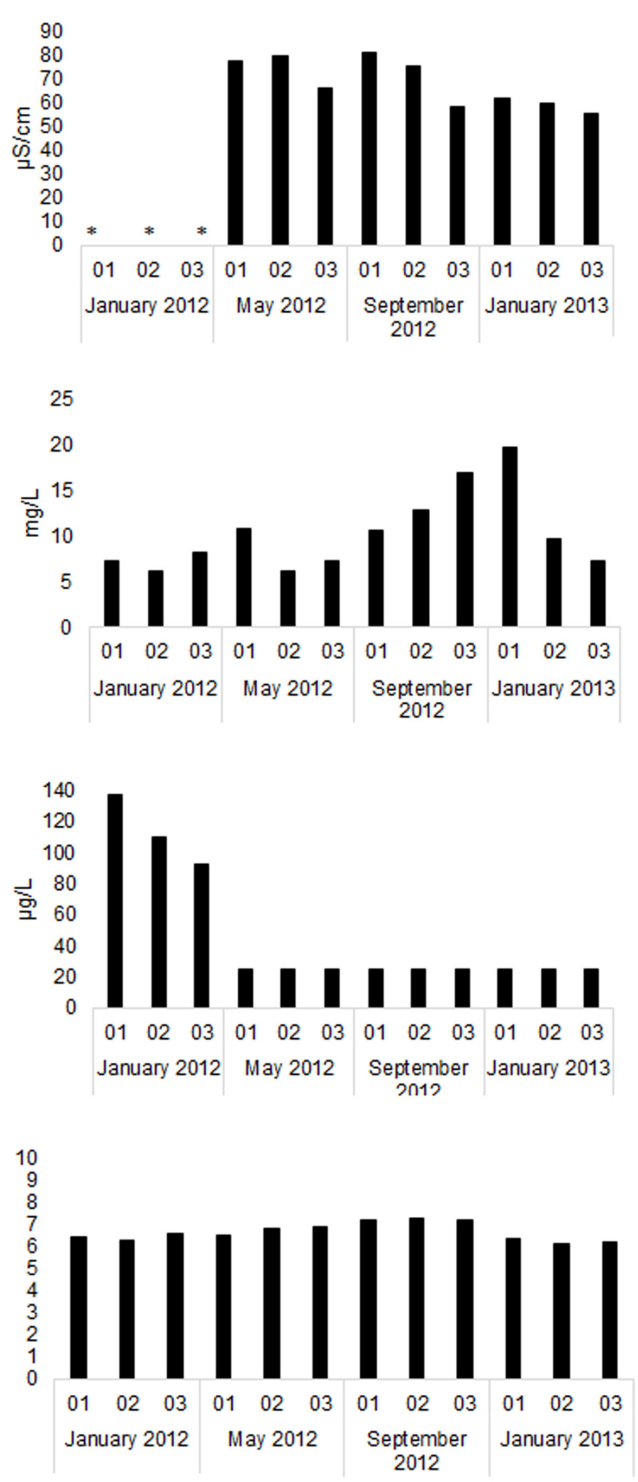

Sampling Date
Itaúba Reservoir

EC

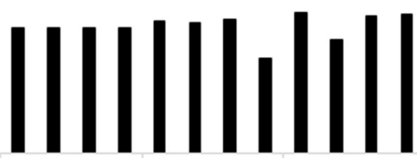

04050607040506070405060704050607

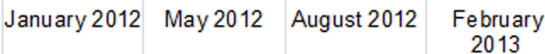

TSS
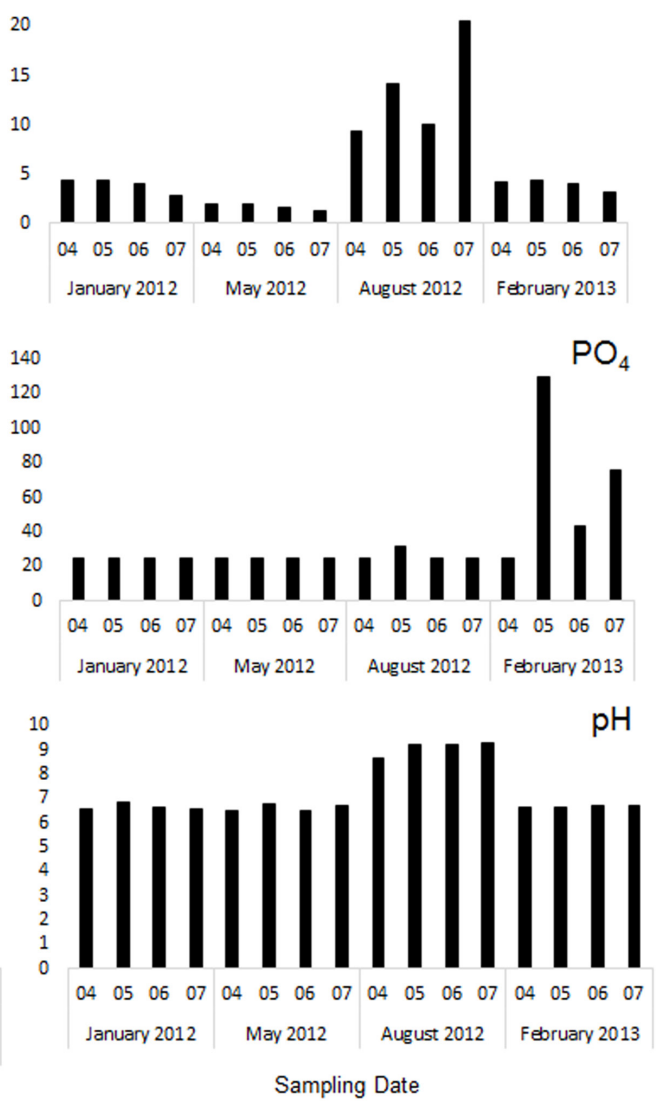

Figure 5. Average electric conductivity (EC), total suspended solids (TSS), phosphate (PO4) and $\mathrm{pH}$ values in Ernestina and Itaúba reservoirs in each sampling site between January 2012 and February 2013. ${ }^{* * *}$ No data collection.
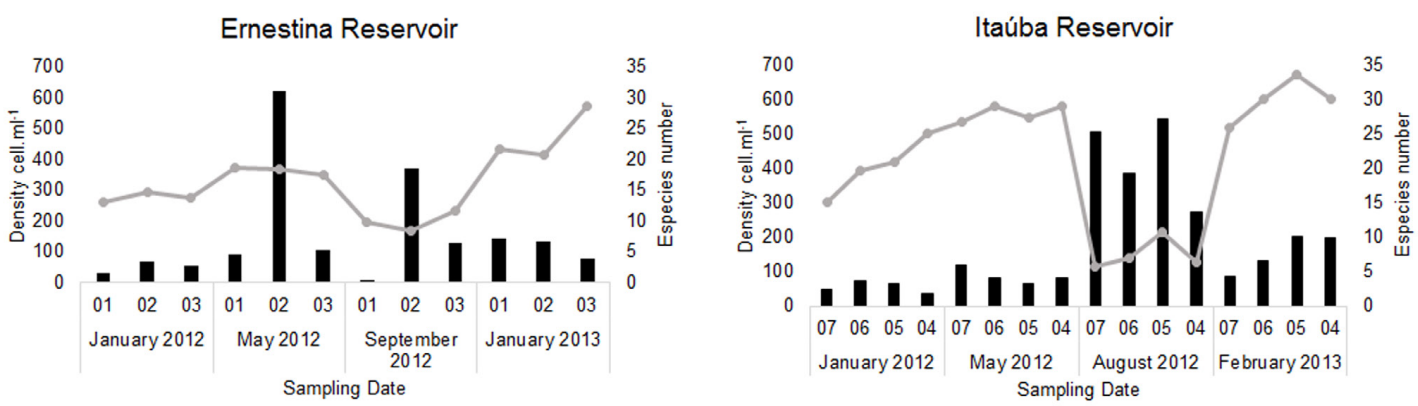

Figure 6. average cell density (bars) and number of species (dots) in each sampling unit in Ernestina (a) and Itaúba (b) reservoirs, between January 2012 and January 2013. 
Euglenophyceae 3\%, Xanthophyceae 2\% and Crysophyceae $1 \% .50$ species were exclusive of this reservoir. The highest species richness was found in May 2012 and February 2013, with an average of 28 species per sample (Figure 6). The lowest species richness, on the other hand, was found in August 2012 (average 7.4 species per sample) due to the dominance of Ceratium furcoides (Levander) Langhans.

The greatest cell density was also found in the winter - 1101 cél. $\mathrm{ml}^{-1}$, in the central zone of the Itaúba reservoir during August 2012 (winter). For biovolume results, phytoplankton classes in both reservoirs are shown in Figure 7. Bacillariophyceae comprised a great portion of the algal biovolume in the first half of 2012 in Ernestina, while Dinophyceae became more important from September until the last sampling trip. Cyanobacterial biovolume was mostly low, only becoming important in the lake zone, close to the Ernestina dam and Chlorophyceae biovolume values were more pronounced in both summer campaigns, January 2012 and January 2013.
The species found with values above $5 \%$ of the total biovolume of any sample are in Table 2 . It is possible to notice that among the most representative species in biovolume, Aulacoseira granulata var. angustissima (O. F. Müller) Simonsen was conspicuous in the first half of the sampling period. After a reduction of this species, a gradual substitution was observed, with the increase of Ceratium furcoides (Levander) Langhans at the Ernestina dam.

Although dominant regarding richness, Chlorophyceae were abundant only in January 2012 in Itaúba reservoir. Dinophyceae increased in biovolume until August 2012, when a peak of this class was reached, decreasing again towards the end of the sampling period. Cyanobacteria were found mostly in the summer also in this reservoir, January 2012 and February 2013. Species of Chlamydophyceae had their highest biovolume along with the Dinophyceae (Figure 7).

The species found with values above $5 \%$ of the total biovolume of any sample in Itaúba are in Table 3. The results indicate that the first sample

\section{Ernestina Reservoir}

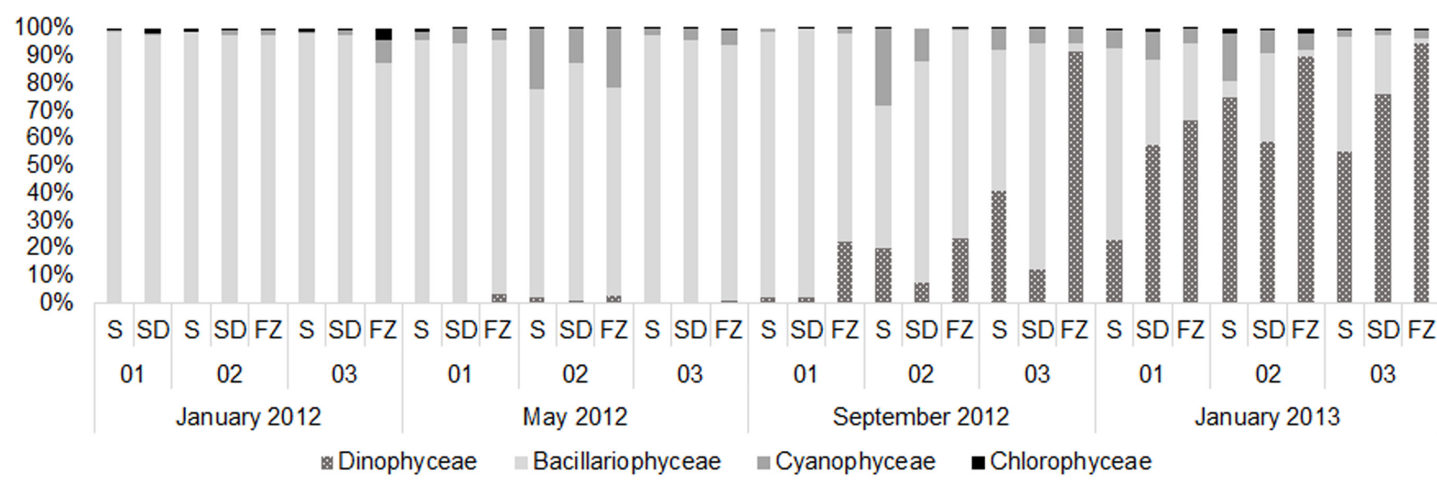

Itaúba Reservoir

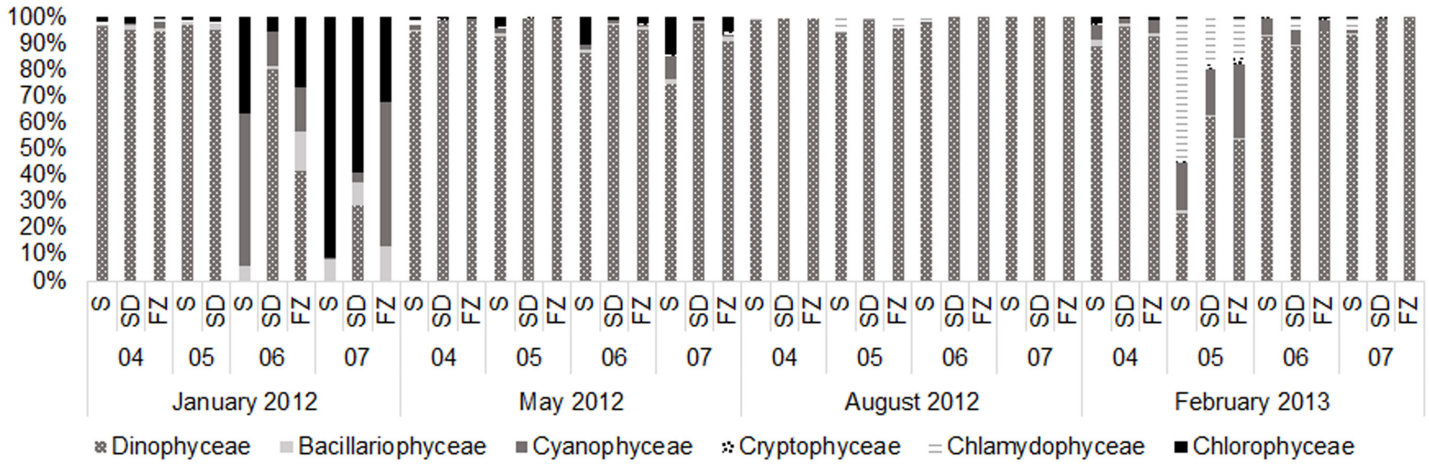

Figure 7. Percentage biovolume $\left(\mu \mathrm{m}^{3} \cdot \mathrm{ml}^{-1}\right)$ of phytoplankton taxonomical classes in Ernestina and Itaúba reservoirs between January 2012 and February 2013. 
Table 2. Average percentage of biovolume referring to the three depths collected from the phytoplankton community in the Ernestina reservoir, RS.

\begin{tabular}{|c|c|c|c|c|c|c|c|c|c|c|c|c|}
\hline \multirow[b]{2}{*}{ SAMPLING SITE } & \multicolumn{3}{|c|}{ January 2012} & \multicolumn{3}{|c|}{ May 2012} & \multicolumn{3}{|c|}{ September 2012} & \multicolumn{3}{|c|}{ January 2013} \\
\hline & 01 & 02 & 03 & 01 & 02 & 03 & 01 & 02 & 03 & 01 & 02 & 03 \\
\hline Ceratium furcoides & & & & & 7 & 11 & 67 & 43 & 23 & 90 & 90 & 75 \\
\hline Dolichospermum circinalis & 7 & & & & 9 & & & & & & & \\
\hline Microcystis sp. & & & & & 9 & & & 13 & & & & \\
\hline Aulacoseira. granulata var angustissima & 87 & 96 & 92 & 88 & 73 & 84 & 40 & 46 & 84 & 10 & & 20 \\
\hline A. granulata var. granulata & 6 & & 6 & & & 9 & & & 27 & & & \\
\hline Cyclotela menenghiniana & 9 & & & & & & & & & & & \\
\hline
\end{tabular}

Table 3. Average percentage of biovolume referring to the three depths collected from the phytoplankton community in Itaúba, reservoir RS.

\begin{tabular}{|c|c|c|c|c|c|c|c|c|c|c|c|c|c|c|c|c|}
\hline & \multicolumn{4}{|c|}{ January 2012} & \multicolumn{4}{|c|}{ May 2012} & \multicolumn{4}{|c|}{ August 2012} & \multicolumn{4}{|c|}{ February 2013} \\
\hline SAMPLING SITE & 04 & 05 & 06 & 07 & 04 & 05 & 06 & 07 & 04 & 05 & 06 & 07 & 04 & 05 & 06 & 07 \\
\hline Ceratium furcoides & & & & & 76 & 73 & 88 & 89 & 100 & 99 & 95 & 99 & 94 & 61 & 25 & 56 \\
\hline $\begin{array}{l}\text { Gymnodinium } \\
\text { austriacum }\end{array}$ & & 18 & & 27 & & & & & & & & & & 7 & & 8 \\
\hline P. umbonatum & & 41 & 43 & 7 & & & & & & & & & & 7 & 7 & \\
\hline P. unconspicum & & & & & & 23 & 14 & 9 & & & & & & & & \\
\hline P.lomnickii & 17 & & & 30 & & & & & & & & & & & & \\
\hline $\begin{array}{l}\text { Peridiniopsis } \\
\text { cunningtonii }\end{array}$ & & 14 & & & & & & & & & & & & & & \\
\hline $\begin{array}{l}\text { Peridinium } \\
\text { gatunense }\end{array}$ & & & 20 & 25 & & & & & & & & & & 29 & 43 & 36 \\
\hline Peridinium $s p$ & & & 15 & 22 & & & & & & & & & & 5 & & \\
\hline $\begin{array}{l}\text { Aulacoseira } \\
\text { granulata var. } \\
\text { granulata }\end{array}$ & 9 & 30 & 6 & 8 & & & & & & & & & & & & \\
\hline $\begin{array}{l}\text { A. granulata var. } \\
\text { angustissima }\end{array}$ & & 14 & & & & & & & & & & & & & & \\
\hline $\begin{array}{l}\text { A. granulata var. } \\
\text { angustissima forma } \\
\text { espiralis }\end{array}$ & & 8 & & & & & & & & & & & & & & \\
\hline $\begin{array}{l}\text { Cyclotela } \\
\text { menenghiniana }\end{array}$ & 42 & 20 & & & & & & & & & & & & & & 10 \\
\hline $\begin{array}{l}\text { Discostella } \\
\text { stelligera }\end{array}$ & & & & & 6 & & & & & & & & & & 5 & \\
\hline Eutetramorus fotti & & 13 & & & & & & & & & & & & & & \\
\hline E. planctonicus & 29 & 8 & & & 6 & & & & & & & & & & & \\
\hline Eudorina sp. & & & & & & & & & & & & & & & 32 & \\
\hline Aphanocapsa sp. & 14 & & & & & & & & & & & & & & & \\
\hline $\begin{array}{l}\text { Dolichospermum } \\
\text { plantonicum }\end{array}$ & & & & & & & & & & & & & & 6 & 16 & \\
\hline Microcystis sp. & 13 & 19 & & & 8 & & & & & & & & & & & \\
\hline
\end{tabular}

campaign was represented by a larger number of species, when compared to the other samplings. It was noticed over the sampling period that the dinoflagellate species Ceratium furcoides, Peridinium gatunense Nygaard, P. umbonatum Stein, and P. lomnickii Woloszynska were predominant in biovolume.

Figure 8 shows bidimensional maps resulting from NMDS analysis, using data from four sampling dates in Ernestina (8a) and Itaúba (8b) reservoir. In Ernestina, the graph displays a seasonal pattern in the phytoplankton community structure, associated with limnological variables. Summer sampling dates - January 2012 and 2013 - were associated to higher temperatures and a slight increase in water transparency. In turn, samples taken in May and September 2012, representing autumn and winter, were linked with increases in total suspended solids and $\mathrm{pH}$.

Considering Figure 8b, samples collected in January 2012 and February 2013 in Itaúba reservoir were associated to increases in water temperature, density decrease of Dinophyceae and slight density of Cyanobacteria (Figure 7). High values of total 

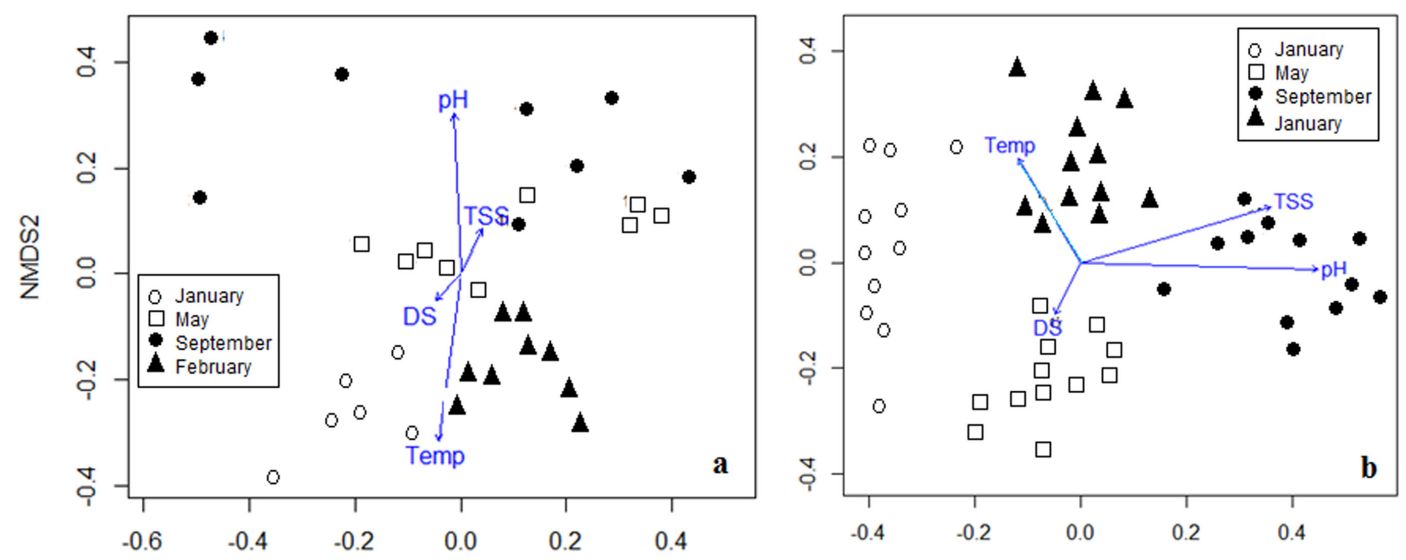

NMDS1

Figure 8. (a) non-metric multidimensional scaling (NMDS) scatter plot of phytoplankton data from Ernestina reservoir. Sampling units are indicated by numbers: (January 2012) empty circle, (May 2012) empty square, (September 2012) full circle, (February 2013) triangle; (b) non-metric multidimensional scaling (NMDS) scatter plot of phytoplankton data from Itaúba reservoir. Sampling units are indicated by numbers: (January 2012) empty circle, (May 2012) empty square, (September 2012) full circle, (January 2013) triangle.

suspended solids and $\mathrm{pH}$ were associated to the higher concentration of cells found in August, due to the intense growth of dinoflagellates. In May, an increase in water transparency was also evidenced by the analysis.

Analysis of similarity (Anosim) showed significant differences in species richness and structure between sampling dates in both Ernestina and Itaúba, but no differences between sampling sites, showing no significant spatial structuring of the community, as shown in Table 4.

\section{Discussion}

Significant differences in the composition of the phytoplankton community were observed only among sampling dates, indicating a strong time-based pattern in the organization of the community. Dissimilarity between communities tends to intensify with increased distance in time (Schneck et al., 2011). The lack of significant differences in spatial organization, both vertically and horizontally, indicates a uniform profile in the reservoir, where the different compartments do not seem to be the main community structuring factor. These results are according with mixing and stability conditions of the water column found, respectively in winter and summer, at Ernestina e Itaúba reservoir. Tundisi et al. (2004, 2010) suggested that water masses tend to mix during winter due to cold weather fronts, lowering water temperature in the surface. However, several authors
Table 4. Similarity index (r) and significance (p) given by the analysis of similarity (Anosim) between sampling dates, depths and sampling sites in Ernestina and Itaúba reservoirs.

\begin{tabular}{lllll}
\hline & & $\begin{array}{c}\text { Sampling } \\
\text { dates }\end{array}$ & Depth & $\begin{array}{c}\text { Sampling } \\
\text { sites }\end{array}$ \\
\hline Ernestina & $\mathrm{r}^{\star}$ & 0.5284 & -0.05071 & 0.04048 \\
& $\mathrm{p}$ & 0.001 & 0.91 & 0.167 \\
Itaúba & $\mathrm{r}$ & 0.8781 & -0.05098 & -0.03673 \\
& $\mathrm{p}$ & 0.001 & 0.984 & 0.86 \\
\hline
\end{tabular}

${ }^{*}$ range $=-1$ to 1 (-1:total similarity and $1:$ total dissimilarity).

have been describing divergent patterns in winter (Branco et al., 2009; Morais et al., 2010).

The highest cell density in the Itaúba reservoir was found after a period of increase of the average residence time from 19 (general average) to 36 days (May to August). Slight Increased water retention time was important in structuring Itaúba reservoir with marked decrease of species richness and increase in dominance of a few species. Increased cell density related to increased water retention time, was also described for other Brazilian reservoirs (Ferrareze \& Nogueira, 2006; Perbiche-Neves et al., 2011). Such environmental conditions favored the development of Ceratium furcoides in high densities, a species adapted to longer water retention periods. On the other hand, In Funil reservoir, Northeastern Brazil, short water residence time caused high chlorophyll 
concentration, due to nutrient enrichment and abundant water flow (Moura et al., 2013).

A similar relation to the increase in cell density associated with the retention time occurred in the Ernestina reservoir, when the highest densities near the spillway coincide with the longer water retention times in 436 days, from March to June, while the general average found was 198 days. However, it was not possible to perceive a change in the phytoplankton community and changes in the representativeness of the class Bacillariophyceae and during this period of growth. When comparing the species found in the reservoirs it is possible to perceive a clear difference in phytoplanktonic composition since these dams have very different characteristics such as morphometry, surrounding vegetation, water retention time and construction. For example, depth of disappearance of the Secchi disk was four times greater in Itaúba compared to Ernestina. Enhanced light penetration causes favourable conditions for the development of phytoplankton. Ernestina is the first reservoir of the cascading system, and receives more drainage water from the surrounding land, with high content of suspended solids, decreasing the depth of the photic zone. Suspended solids intercept scattering of solar light, consequently affecting primary production. On the other hand, in Itaúba reservoir the presence of dense vegetation surrounding the lake and obstructing the wind, increased water transparency and increased retention time were favourable conditions for the greater phytoplankton cell density. Such conditions were also reported by Soares et al. (2008) in another lake in Southern Brazil.

Alkaline $\mathrm{pH}$ (between 8.2 and 9.3), and heterogeneous temperature profiles of the water column were present in high densities of Ceratium furcoides from 100 cél. $\mathrm{ml}^{-1}$. This dinoflagellate species has been reported occurring in alkaline $\mathrm{pH}$ in other reservoirs in Brazil (Matsumura-Tundisi et al., 2010; Silva et al., 2012), South America (Gil et al., 2012; Silverio et al., 2009), Europe (Ginkel et al., 2001; Echevarría \& Rodríguez, 1994) and Africa (Donagh et al., 2005). Our results showed that high cell densities were registered in sampling sites with alkaline $\mathrm{pH}$ and also high dissolved oxygen level, which may be associated with increased phytoplankton photosynthetic activity.

In total, 148 species were identified in the two reservoirs of the cascade system. This number was lower than the 336 taxa observed by Schneck et al.
(2011) in Dona Francisca reservoir, which is situated in the same system, but further downstream of Itaúba and Ernestina. These authors also observed Chlorophyceae as the most species rich group, similar to the situation we found. Other studies have reported this group as the main contributor to richness in phytoplankton communities, such as Nogueira et al. (2010) in a cascading reservoir system of the river Paranapanema, Padisák et al. (2000) and Silva et al. (2005) in the River Plata and Borges et al. (2008) in the River Iguassu. Rodrigues et al. (2007) have found high richness of green algae in the River Jacuí Delta, and concluded that they are favored by increased average temperatures.

Density, biovolume and richness of planktonic diatoms (Bacillariophyceae) were more significant in Ernestina, with isothermal conditions, indicating mixing of the water layers in the first half of 2012. These homogenous conditions may limit primary productivity of plankton and cause increase in suspended materials in the water column, favouring species which are adapted to these conditions, such as A. granulata var. granulata (Reynolds et al., 2002). Heterogeneous conditions of temperature and dissolved oxygen indicate less stability of the water column in Itaúba, intensifying the development of Ceratium furcoides, species that is sensitive to mixing (Reynolds et al., 2002).

Some trends described by Barbosa et al. (1999) for the cascading reservoir continuum concept, such as decreasing suspended matter, increased mixing depth and increase richness species along the system were found in our study. However, phytoplankton distribution patterns and water temperature responded to local features of each reservoir, not following the continuum assumptions. Silva et al. (2005), Nogueira et al. (2010), and Perbiche-Neves et al. (2011) also found patterns in cascading reservoirs that did not conform to the continuum concept. Thus, morphometric features of each reservoir as well surrounding land use rise as the important influential factors on community structure (Borges et al., 2008).

\section{Conclusions}

Phytoplankton community structure in the Jacuí Cascade System responded to seasonal variation and to each reservoir set of characteristic. We suggest, for purposes of monitoring and maintaining the water quality of the Jacuí River Basin, that these primary community regulatory forces should be considered, so that adequate measures can be established for each reservoir and allow a continuous assessment 
of the system. Designing a management system that promotes the integration of biotic and abiotic data is essential to these resources of recognized importance for the population and the country's power generation.

\section{Acknowledgements}

Authors would like to thank CAPES Foundation for two MSc scholarships, CNPq (Brazilian Research Council) for funding, Industrial Chemical Analyses Laboratory at UFSM for water analyses.

\section{References}

AMERICAN PUBLIC HEALTH ASSOCIATION APHA. Standard methods: for the examination of water and wastewater. 21 th ed. Washington: APHA, 2005.

BARBOSA, F.A.R., PADISÁK, J., ESPÍNDOLA, E.L.G., BORICS, G. and ROCHA, O. 1999. The Cascading Reservoir Continuum Concept (CRCC) and its Aplication to the River Tietê-Basin, São Paulo State, Brazil. In: J.G. TUNDISI and M. Straskraba. Theorical reservoir ecology and its applications. Leiden: International Institute of Ecology, Brazilian Academy of Sciences and Backhuys Publishers, pp. 425-437.

BICUDO, C.E.M. and MENEZES, M. 2006. Gêneros de algas de águas continentais do Brasil: chave para identificação e descriçôes. 2. ed. São Carlos: Rima.

BORGES, F.P.A., TRAIN, S. and RODRIGUES, L.C. Spatial and temporal variation of phytoplankton in two subtropical Brazilian reservoirs. Hydrobiologia, 2008, 607(1), 63-74. http://dx.doi.org/10.1007/ s10750-008-9367-3.

BRANCO, W.C., KOZLOWSKY-SUZUKI, B., SOUSA-FILHO, I.F., GUARINO, A.W.S. and ROCHA, R.J. Impact of climate on the vertical water column structure of Lajes Reservoir (Brazil): a tropical reservoir case. Lakes and Reservoirs: Research and Management, 2009, 14(3), 175-191. http://dx.doi. org/10.1111/j.1440-1770.2009.00403.x.

CASSOL, A.P.V., PEREIRA FILHO, W., OLIVEIRA, M.A., DOMINGUES, A.L., CORREA, F.S. and BURIOL, G.A. First record of a bloom of the invasive species Ceratiumfurcoides (Levander) Langhans 1925 in Rio Grande do Sul state, Brazil. Brazilian Journal of Biology = Revista Brasileira de Biologia, 2014, 74(2), 515-517. PMid:25166340. http://dx.doi. org/10.1590/1519-6984.05413.

CENTRO ESTADUAL DE METEOROLOGIA - CEMET. Atlas climático do Rio Grande do Sul [online]. Porto Alegre: CEMET, 2012 [viewed 8 Jan. 2014]. Available from: http://www.cemet.rs.gov. br/lista/676/Atlas_Clim\%C3\%A1tico_do_Rio_ Grande_do_Sul

COMPANHIA ESTADUAL DE GERAÇÃO E TRANSMISSÃO DE ENERGIA ELÉTRICA -
CEEE-GT. Plano de uso e ocupação do solo no entorno do reservatório da UHE Ernestina. Rio Grande do Sul: CEEE, 2010a.

COMPANHIA ESTADUAL DE GERAÇÃO E TRANSMISSÃO DE ENERGIA ELÉTRICA CEEE-GT. Plano de uso e ocupação do solo no entorno do reservatório da UHE Itaúba. Rio Grande do Sul: CEEE, 2010b.

DONAGH, M.E., CASCO, M.A. and CLAPS, M.C. Colonization of a Neotropical Reservoir (Córdoba, Argentina) by Ceratiumhirundinella (O. F. Müller) Bergh. Annales de Limnologie - International Journal of Limnology, 2005, 41(4), 291-299. http://dx.doi. org/10.1051/limn/2005020.

ECHEVARRÍA, F. and RODRÍGUEZ, J. The size structure of plankton during a deep bloom in a stratified Reservoir. Hydrobiologia, 1994, 284, 113124. http://dx.doi.org/10.1007/BF00006883.

ESTEVES, F.A. Fundamentos em limnologia. Rio de Janeiro: Ed. Interciência/FINEP, 1998. 602 p.

FERRAREZE, M. and NOGUEIRA, M.G. Phytoplankton assemblages and limnological characteristics in lotic systems of the Paranapanema Basin (Southeast Brazil). Acta Limnologica Brasiliensia, 2006, 18(4), 389-405.

GIL, C.B., RESTREPO, J.J.R., BOLTOVSKOY, A. and VALLEJO, A. Spatial and temporal change characterization of Ceratiumfurcoides (Dinophyta) in the equatorial reservoir Riogrande II, Colombia. Acta Limnologica Brasiliensia, 2012, 24(2), 207-219. http:// dx.doi.org/10.1590/S2179-975X2012005000039.

GINKEL, C.V., HOHLS, B.C. and VERMAAKA, E. Ceratiumhirundinella (O.F. Müller) bloom in Hartbeespoort Dam, South Africa. Water S.A., 2001, 27(2), 269-276.

GOMES, L.C. and MIRANDA, L.E. Hydrologic and climatic regimes limit phytoplankton biomass in reservoirs of the Upper Parana River Basin, Brazil. Hydrobiologia, 2001, 457(1/3), 205-214. http:// dx.doi.org/10.1023/A:1012295901870.

HILLEBRAND, H., DÜRSELEN, C., KIRSCHTEL, D., POLLINGHER, U. and ZOHARY, T. Biovolume calculation for pelagic and benthic microalgae. Journal of Phycology, 1999, 35(2), 403-424. http:// dx.doi.org/10.1046/j.1529-8817.1999.3520403.x.

INSTITUTO NACIONAL DE METEOROLOGIA - INMET. Brasília: INMET, 2013 [viewed 5 Mar. 2013]. Available from: http://www.inmet.gov.br/ portal/index.php?r=bdmep/bdmep

KIMMEL, B.L., LIND, O.T. and PAULSON, J.L. 1990. Reservoir primary production. In: K.W. THORTON, B.L. KIMMEL and F.E. PAYNE. Reservoir limnology: ecological perspectives. New York: John Wiley and sons, pp. 133-193.

MATSUMURA-TUNDISI, T., TUNDISI, J.G., LUZIA, A.P. and DEGANI, R.M. Occurrence 
of Ceratiumfurcoides (Levander) Langhans 1925 bloom at the Billings Reservoir, São Paulo State, Brazil. Brazilian Journal of Biology $=$ Revista Brasileira de Biologia, 2010, 70(3), 825-829. Supplement. PMid:21085787. http://dx.doi.org/10.1590/S151969842010000400013

MORAIS, M.A., CASTRO, W.A.C. and TUNDISI, J.G. Climatologia de frentes frias sobre a região metropolitana de São Paulo (rmsp), e sua influência na limnologia dos reservatórios de abastecimento de água. Revista Brasileira de Meteorologia, 2010, 25(2), 205-217. http://dx.doi.org/10.1590/S010277862010000200005 .

MOURA, A.N., SEVERIANO, J.S., TAVARES, N.K.A. and DANTAS, E.W. The role of a cascade of reservoirs and seasonal variation in the phytoplankton structure in a tropical river. Brazilian Journal of Biology = Revista Brasileira de Biologia, 2013, 73(2), 291-298. PMid:23917556. http://dx.doi. org/10.1590/S1519-69842013000200009.

NOGUEIRA, M.G., FERRAREZE, M., MOREIRA, M.L. and GOUVÊA, R.M. Phytoplankton assemblages in a reservoir cascade of a large tropical - subtropical river (SE, Brazil). Brazilian Journal of Biology = Revista Brasileira de Biologia, 2010, 70(3), 781-793. Supplement. PMid:21085783. http:// dx.doi.org/10.1590/S1519-69842010000400009.

OKSANEN, J., BLANCHET, F.G., KINDT, R., LEGENDRE, P., MINCHIN, P.R., O'HARA, R.B., SIMPSON, G.L., SOLYMOS, P., STEVENS, M.H.H. and WAGNER, H. Vegan: community ecology package. $R$ package version 2.0-10 [online]. Vienna: The R Foundation for Statistical Computing, 2009 [viewed 5 Mar. 2013]. Available from: http:// CRAN.R-project.org/package $=$ vegan

OPERADOR NACIONAL DO SISTEMA ELÉTRICO - ONS. [online]. Rio de Janeiro: ONS, 2013 [viewed 28 Feb. 2013]. Available from: http://www.ons.org. br/resultados_operacao/ophen.aspx

PADISÁK, J., BARBOSA, F.A.R., BORBÉLY, G., BORICS, G., CHORUS, I., ESPINDOLA, E.L.G., HEINZE, R., ROCHA, O., TÖRÖKNE, A.K. and VASAS, G. Phytoplankton composition, biodiversity and a pilot survey of toxic cyanoprokaryotes in a large cascading reservoir system (Tietê basin, Brazil). International Association of Theoretical and Applied Limnology Proceeding, 2000, 27(5), 2734-2742.

PERBICHE-NEVES, G., FERREIRA, R.A.R. and NOGUEIRA, M.G. Phytoplankton structure in two contrasting cascade reservoirs (Paranapanema River, Southeast Brazil). Biologia, 2011, 66(6), 967-976. http://dx.doi.org/10.2478/s11756-011-0107-1.

R CORE TEAM. $R$ : a language and environment for statistical computing [online]. Vienna: R Foundation for Statistical Computing, 2013 [viewed 28 Feb. 2013]. Available from: http://www.R-project.org/
REYNOLDS, C.S., HUSZAR, V., KRUK, C., NASELLI-FLORES, L. and MELO, S. Towards a functional classification of the freshwater phytoplankton. Journal of Plankton Research, 2002, 24(5), 417-428. http://dx.doi.org/10.1093/ plankt/24.5.417.

REYNOLDS, C.S. Ecology of phytoplankton. Cambrigde: Cambrigde University Press, 2006. 535 p.

RODRIGUES, L.M., SCHWARZBOLD, A. and OLIVEIRA, M.A. Spatial and temporal variation of Dona Francisca reservoir (Jacuí river, Rio Grande do Sul State), a subtropical reservoir. Acta Scientiarum. Biological Sciences, 2012, 34(3), 279-288. http:// dx.doi.org/10.4025/actascibiolsci.v34i3.10078.

RODRIGUES, S.C, TORGAN, T., SCHWARZBOLD, A. Composição e variação sazonal da riqueza do fitoplâncton na foz de rios do delta do Jacuí, RS, Brasil. Acta Botanica Brasiliense, 2007, 21(3), 707721.

SCHNECK, F., SCHWARZBOLD, A., RODRIGUES, S.C. and MELO, A.S. Environmental variability drives phytoplankton assemblage persistence in a subtropical reservoir. Austral Ecology, 2011, 36(7), 839-848. http://dx.doi.org/10.1111/j.14429993.2010.02224.x.

SILVA, C.A., TRAIN, S. and RODRIGUES, L.C. Phytoplankton assemblages in a Brazilian subtropical cascading reservoir system. Hydrobiologia, 2005, 537(1-3), 99-109. http://dx.doi.org/10.1007/ s10750-004-2552-0.

SILVA, L.C., LEONE, I.C., SANTOS-WISNIEWSKI, M.J.S., PERET, A.C. and ROCHA, O. Invasion of the dinoflagellate Ceratiumfurcoides (Levander) Langhans 1925 at tropical reservoir and its relation to environmental variables. Biota Neotropica, 2012, 12(2), 93-100. http://dx.doi.org/10.1590/S167606032012000200010.

Silverio, M.J., MONTAŃEZ, G., FrA, E., SARACHO, M., ARJONA, M., AMAYA, S. and TRACCANNA, B. Variación poblacional de Ceratiumbirundinella (Dinophyceae) en Embalses Eutróficos de Catamarca (Argentina) y surelacióncon Parámetros Ambientales. Huayllu-Bios, 2009, 3, 13-31.

SMITH, W.S., ESPÍNDOLA, E.L.G. and ROCHA, O. Environmental gradient in reservoirs of the medium and low Tietê River: limnological differences through the habitat sequence. Acta Limnologica Brasiliensia, 2014, 26(1), 73-88. http://dx.doi.org/10.1590/ S2179-975X2014000100009.

SOARES, M.C.S., MARINHO, M.M., HUSZAR, V.L.M., BRANCO, C.W.C. and AZEVEDO, S.M.F.O. The effects of water retention time and watershed features on the limnology of two tropical reservoirs in Brazil. Lakes and Reservoirs: Research and Management, 2008, 13(4), 257-269. http://dx.doi. org/10.1111/j.1440-1770.2008.00379.x. 
SPELLMAN, F.R. The science of water: concepts and applications. 2nd ed. Boca Raton: CRC Press, 2008.

SUN, J. and LIU, D. Geometric models for calculating cell biovolume and surface area for phytoplankton. Journal of Plankton Research, 2003, 25(11), 13311346. http://dx.doi.org/10.1093/plankt/fbg096.

TORGAN, L.C., BUSELATO, T.C. and FERRAZ, G.C. Floraçấo de Aphanizomenonflos-aquae (L.) Ralfsex Born, et Flash., (Cyanophyeae) na represa de Itaúba, Rio Grande do Sul. Iheringia Série Botânica, 1981, 26, 45-64.

TUNDISI, J.G. and MATSUMURA-TUNDISI, $T$. Integration of research and management in optimizing multiple uses of reservoirs: the experience in South America and Brazilian case studies. Hydrobiologia, 2003, 500(1-3), 231-242. http:// dx.doi.org/10.1023/A:1024617102056.

TUNDISI, J.G., MATSUMURA-TUNDISI, T., ARANTES JÚNIOR, J.D., TUNDISI, J.E., MANZINI, N.F. and DUCROT, R. The response of Carlos Botelho (lobo, broa) Reservoir to the passage of cold fronts as Reflected by physical, chemical, and Biological variables. Brazilian Journal of Biology $=$ Revista Brasileira de Biologia, 2004, 64(1), 177-186.
PMid:15195377. http://dx.doi.org/10.1590/S151969842004000100020.

TUNDISI, J.G., MATSUMURA-TUNDISI, T., PEREIRA, K.C., LUZIA, A.P., PASSERINI, M.D., CHIBA, W.A.C., MORAIS, M.A. and SEBASTIEN, N.Y. Cold fronts and reservoir limnology: an integrated approach towards the ecological dynamics of freshwater ecosystems. Brazilian Journal of Biology $=$ Revista Brasileira de Biologia, 2010, 70(3), 815-824. Supplement. PMid:21085786. http://dx.doi.org/10.1590/S151969842010000400012 .

UTERMÖHL, H. On the perfecting of quantitative phytoplankton method. International Association of Theoretical and Applied Limnology Proceeding, 1958, 9, 1-38.

WERNER, V.R. and LAUGHINGHOUSE IV, H.D. Bloom-forming and other planctonic Anabaena (Cyanobacteria) morphoespecies with twisted trichomes from Rio Grande do Sul State, Brazil. Nova Hedwigia, 2009, 89(1), 17-47. http://dx.doi. org/10.1127/0029-5035/2009/0089-0017.

Received: 05 September 2016 Accepted: 13 November 2017 